\title{
Family caregivers' experience in the process of caring for older adults: a qualitative
}

\section{synthesis}

\author{
Experiência de cuidadores familiares no processo de cuidar de idosos: uma síntese qualitativa \\ La experiencia de los cuidadores familiares en el proceso de cuidado de los adultos mayores: una \\ síntesis cualitativa
}

Received: 08/30/2021 | Reviewed: 09/05/2021 | Accept: 09/10/2021 | Published: 09/12/2021

Cristiane de Paula Rezende

ORCID: https://orcid.org/0000-0001-7457-4187 Federal University of Minas Gerais, Brazil E-mail: cris7paula@gmail.com

Mariana Martins Gonzaga do Nascimento ORCID: https://orcid.org/0000-0003-2183-4365 Federal University of Minas Gerais, Brazil E-mail: marianamgn@yahoo.com.br

Aline Silva de Assis Santos ORCID: https://orcid.org/0000-0002-2652-1977 Federal University of Minas Gerais, Brazil E-mail: assisaline2012@gmail.com

Isabela Viana Oliveira ORCID: https://orcid.org/0000-0001-7846-5914 Federal University of Minas Gerais, Brazil E-mail: isabelaviana.far@gmail.com

Agnes Fonseca Ribeiro Filardi

ORCID: https://orcid.org/0000-0002-0685-2402 Federal University of Minas Gerais, Brazil E-mail: agnesfrf@gmail.com

Yone de Almeida Nascimento

ORCID: https://orcid.org/0000-0002-5897-0160 Federal University of Minas Gerais, Brazil E-mail: yone.almeida1@gmail.com

Djenane Ramalho de Oliveira

ORCID: https://orcid.org/0000-0002-5548-8184 Federal University of Minas Gerais, Brazil E-mail: djenane.oliveira@gmail.com

\begin{abstract}
In this review, the main goal was to answer the question: What are the family caregivers' experiences in the process of providing care to older people? To do so, a systematic literature review was carried out by consulting the MEDLINE, Cochrane, and Lilacs databases. Two reviewers selected the studies independently, and discrepancies were sorted out by a third reviewer. The Critical Appraisal Skills Programme was used to evaluate the methodological quality of the included studies, and thematic analysis was applied to synthesize the results. The analytical themes addressed in the synthesis were developed through researchers' interpretations and new constructs. Confidence in the findings was reviewed using GRADE-CERQual. The study adhered to Enhancing Transparency in Reporting the Synthesis of Qualitative Research guidelines. Eighteen studies were included in the synthesis. Three analytical themes emerged: "Mixed feelings", "You have no life. Your own life gets put on hold", and "The need for increasing coping strategies". Several conflicting feelings emerged in the process of care, showing the complexity of the caregivers' experience. Either way, the caregivers put their lives on hold to provide care and sought coping strategies, such as formal and informal support and spirituality. Therefore, both health professionals and policymakers must ensure comprehensive care for the older adults and their families, so that caregivers do not compromise their own lives and health in order to take care of others.
\end{abstract}

Keywords: Systematic review; Qualitative research; Aged; Frail elderly; Caregivers.

\section{Resumo}

Nesta revisão, o objetivo principal foi responder à questão: Quais são as experiências dos cuidadores familiares no processo de cuidar dos idosos? Para isso, foi realizada uma revisão sistemática da literatura por meio de consulta às bases de dados MEDLINE, Cochrane e Lilacs. Dois revisores selecionaram os estudos de forma independente, e as discrepâncias foram resolvidas por um terceiro revisor. O instrumento Critical Appraisal Skills Programme foi 
utilizado para avaliar a qualidade metodológica dos estudos incluídos, e a análise temática foi adotada para sintetizar os resultados. Os temas analíticos abordados na síntese foram desenvolvidos por meio de interpretações e novas construções dos pesquisadores. A confiança nestes resultados foi revisada usando o GRADE-CERQual. O estudo aderiu às diretrizes Enhancing Transparency in Reporting the Synthesis of Qualitative Research. Dezoito estudos foram incluídos na presente síntese. Emergiram três temas analíticos: "Sentimentos confusos", "Você não tem vida. Sua própria vida fica suspensa" e "A necessidade de melhorar as estratégias de enfrentamento". Diversos sentimentos conflitantes emergiram no processo de cuidar, evidenciando a complexidade da experiência dos cuidadores. Independentemente dos sentimentos, os cuidadores suspenderam a vida para cuidar e buscaram estratégias de enfrentamento, como apoio formal e informal e espiritualidade. Portanto, tanto os profissionais de saúde quanto os formuladores de políticas devem garantir o cuidado integral ao idoso e seus familiares, para que assim, o cuidador não comprometa sua própria vida e saúde para cuidar do outro.

Palavras-chave: Revisão sistemática; Pesquisa qualitativa; Idoso; Idoso frágil; Cuidadores.

\section{Resumen}

En esta revisión, el objetivo principal fue responder a la pregunta: ¿Cuáles son las experiencias de los cuidadores familiares en el proceso de proporcionar atención a las personas mayores? Para ello, se realizó una revisión sistemática de la literatura consultando las bases de datos MEDLINE, Cochrane y Lilacs. Dos revisores seleccionaron los estudios de forma independiente y un tercer revisor resolvió las discrepancias. Se utilizó el Critical Appraisal Skills Programme para evaluar la calidad metodológica de los estudios incluidos y se aplicó el análisis temático para sintetizar los resultados. Los temas analíticos abordados en la síntesis se desarrollaron a través de las interpretaciones de los investigadores y los nuevos constructos. La confianza en los resultados se revisó mediante GRADE-CERQual. Se adhirió a la guía Enhancing Transparency in Reporting the Synthesis of Qualitative Research. Se incluyeron dieciocho estudios en la síntesis. Surgieron tres temas analíticos: "Sentimientos encontrados", "No tienes vida. Tu propia vida queda en suspenso" y "La necesidad de incrementar las estrategias de afrontamiento". Varios sentimientos conflictivos surgieron en el proceso de cuidado, mostrando la complejidad de La experiencia de los cuidadores. De cualquier manera, los cuidadores posieron sus vidas en suspenso para proporcionar cuidados y buscaron estrategias de afrontamiento, como apoyo formal, informal y espiritualidad. Por lo tanto, tanto los profesionales de la salud como los formuladores de políticas deben garantizar una atención integral a los adultos mayores y sus familias, para que los cuidadores no comprometan su propia vida y salud para cuidar de los demás.

Palabras clave: Revisión sistemática; Investigación cualitativa; Anciano; Anciano frágil; Cuidadores.

\section{Introduction}

Populations all over the world are aging, and it is estimated that there will be two billion people over sixty years old in 2050 (WHO, 2015, 2017). With the increase in the number of older people, more people will be exposed to the risk of developing disabling and complex noncommunicable, chronic diseases, which can lead to loss of autonomy, difficulties with carrying out activities of daily living, and the need for caregivers (WHO, 2015, 2017). It is estimated that 101 million people 60 years old or older worldwide already depend on care (WHO, 2017).

In most countries, older people often keep living in their homes even after losing their autonomy, which involves the need to offer them home care. Consequently, their relatives (spouses, children, children-in-law, or other relatives) get involved in care activities, taking up the role of caregivers of their older and more dependent relatives (Hashizume, 2010; Peacock et al., 2017; WHO, 2017). This structure for the process of providing care to older people in communities has become a concern worldwide, given that it negatively impacts caregivers' health (WHO, 2017). When caregivers dedicate themselves to caring for older adults, they experience situations of conflict, tension, physical and emotional stress, social isolation and work overload, which can lead them to health problems (Garner \& Faucher, 2014; Hashizume, 2010; Horrell, Stephens, \& Breheny, 2015; Lane, McKenna, Ryan, \& Fleming, 2003; Larrañaga et al., 2009; Six, Musomi, \& Deschepper, 2019; WHO, 2017; Williams et al., 2016). In parallel, historical family rearrangements have been decreasing the proportion of younger people who can contribute to care and reducing the time available to women, who are the traditional caregivers in their families, but have increasingly been occupying other social and economic positions (Hashizume, 2010; Larrañaga et al., 2009; WHO, 2017). The result is that higher levels of dependence of older people have a major impact on family, social, and economic dynamics and may overload caregivers (Larrañaga et al., 2009). 
Among the studies that adressed the family caregivers, there have been some qualitative syntheses that described the experience of caregivers of older adults with dementia (Cabote, Bramble, \& McCann, 2015; Domingues, Verreault, \& Hudon, 2018; McCabe, You, \& Tatangelo, 2016; Watson, Tatangelo, \& McCabe, 2019). There have also been published some reviews which approached some particular aspects of the caring experience, such as: caregivers' experience with care transitions (Jacobson, Gomersall, Campbell, \& Hughes, 2015; Parker, Hickman, Phillips, \& Ferguson, 2020); experience of caregivers who are over 75 years old (Greenwood \& Smith, 2016); and informal carers' experiences when caring for older people with a hip fracture (Saletti-Cuesta, Tutton, Langstaff, \& Willett, 2018). Additionally, systematic review and meta-analysis were identified (Del-Pino-Casado, Rodríguez Cardosa, López-Martínez, \& Orgeta, 2019; Domingues et al., 2018; Ge \& Mordiffi, 2017; Greenwood \& Smith, 2015; Parker et al., 2020; Ringer, Hazzan, Agarwal, Mutsaers, \& Papaioannou, 2017; Watson et al., 2019). However, none of these studies fully captured the experience of family caregivers in the process of caring for older adults people.

Therefore, conducting a synthesis of qualitative evidence can be useful for understanding the caregivers' experience in the complex scenario of comprehensive care for the older people in their home environment. Synthesizing qualitative findings in the literature is justified, because it expands the set of evidence related to a certain phenomenon, given that it gathers information produced by relevant research and, at the same time, respects and preserves its context and complexity (Thomas \& Harden, 2008). Qualitative evidence has the potential to contribute to policymaking (Lewin, Booth, et al., 2018) and the humanization of decision-making processes in health systems, because it brings together the opinions and experiences of those affected by an intervention or its absence (Lewin, Bohren, et al., 2018; Lewin, Booth, et al., 2018).

However, to the best of our knowledge, no synthesis of evidence was found about the experience of older adults' caregivers in a broader point of view, without specifying and focusing on an specific disease or circumstance. Such a review is important to broaden the understanding of the meaning related to the care process from the perspective of older adults' caregivers, and to raise awareness towards the implementation of actions to support, train, and provide care to family caregivers who look after dependent older people. Adding to the base evidence, this review seeks to answer the question: What are the family caregivers' experiences in the process of providing care to older people?

\section{Methodology}

The qualitative synthesis is used to synthesize the results of several researches published in scientific journals and selected according to the focused object (Turato, 2005). Thus, results from different contexts are gathered, which can generate new theoretical or conceptual models, providing evidence for the development, implementation, and evaluation of health interventions, in addition to enabling the identification of gaps in scientific knowledge (Colvin et al., 2018; Glenton et al., 2018; Lewin, Bohren, et al., 2018; Munthe-Kaas et al., 2018; Noyes et al., 2018; Tong, Flemming, McInnes, Oliver, \& Craig, 2012).

Therefore, the synthesis of qualitative evidence comprises a methodology in which the reviewer analyzes the results of primary qualitative studies that address the same theme, or related themes; in other words, an analysis of the results and conclusions of different primary studies is carried out in search of new interpretations (Sandelowski \& Barroso, 2007; Thorne, Jensen, Kearney, Noblit, \& Sandelowski, 2004; Zimmer, 2006). Thus, the validity of these findings is not related to the logic of replication of the data, or to the mere comparison of them, but to the interpretative logic which generates new findings reformulated and transformed into the final product (Sandelowski \& Barroso, 2007; Zimmer, 2006).

The methodologies used for the qualitative synthesis are influenced by different aspects, such as: the research question, intended result in the development of the synthesis, reviewer's philosophical position, context, and target audience (Tong et al., 2012). The methodology used in this research, called thematic synthesis, was developed by Thomas e Harden 
(2008). When using this methodology, the reviewers 'go beyond' the primary studies generating new interpretive constructs, explanations or hypotheses to phenomena under analysis. Thomas e Harden (2008) follow the epistemological position of critical realism, considering that knowledge of reality is mediated by our perceptions and beliefs. Although the reviewers present a less problematized view of reality and a greater assumption that their synthetic products are reproducible and correspond to a shared reality, it is with the thematic synthesis methodology that they interpret data and construct new realities (Barnett-Page \& Thomas, 2009; Thomas \& Harden, 2008).

Following the assumptions of critical realism, the thematic synthesis is characterized by a more linear approach to research. For this reason, the reviewers examine the quality of the studies included and seek to answer the research questions instead of exploring and problematizing the findings of the literature. It is important to highlight that the results of this methodology are designed to provide information for policy makers and health professionals (Barnett-Page \& Thomas, 2009; Thomas \& Harden, 2008).

Additionally, it should also be noted that the thematic synthesis is mirrored in traditional methods of systematic reviews. It is with these methods that are performed broad, standardized and systematic searches in the literature for primary studies. That happens in order to bring together all relevant studies to represent the phenomenon of interest (Barnett-Page \& Thomas, 2009; Booth, 2016; Thomas \& Harden, 2008; Tong et al., 2012). Then, all the steps performed in the present study are described.

\subsection{Methods}

A qualitative synthesis of evidence was carried out by applying thematic analysis, as proposed by Thomas and Harden (2008). The present manuscript was drafted by following the Enhancing Transparency in Reporting the Synthesis of Qualitative Research (ENTREQ) statement, a standardized reporting guideline containing 21 items grouped into five domains (introduction, methods and methodology, literature search and selection, appraisal, and synthesis of findings) (Tong et al., 2012).

\subsubsection{Search strategy}

A systematic search for qualitative studies was performed, following the Preferred Reporting Items for Systematic Reviews and Meta-Analyses (PRISMA) guidelines (Moher et al., 2015). The bibliographic search was carried out by consulting the MEDLINE (PubMed), Cochrane (CENTRAL), and Latin American and Caribbean Health Sciences Literature (LILACS) databases in November 2018.

The search strategy of the present study was designed by using an adaptation of the PICO model into PICo (with a lower case "o"), in which "P" refers to participants, "I" indicates the phenomenon of interest, and "Co" denotes the context (Stern, Jordan, \& McArthur, 2014). For each database, a specific strategy was developed with MeSH descriptors (("Caregivers") AND (“Qualitative Research" OR "Narrative Medicine” OR "Personal Narratives as Topic") AND (“Aged" OR "Frail Elderly")) and the combinations with their synonyms.

For the manual search, the authors verified whether there were any papers addressing the subject of the present qualitative synthesis in the Journal of Clinical Nursing from 2017 to September 2019 and searched the reference lists of the included studies. Grey literature (theses and Google Scholar) was also searched.

\subsubsection{Eligibility criteria}

In relation to the inclusion of articles for this study, the following inclusion criteria were used:

- Articles published and indexed in English, Spanish, or Portuguese however no limit on the date of publication was 
applied;

- Published qualitative studies that used interviews, focus groups/group discussions, or observations (studies using mixed research methods were not included);

- Studies including caregivers of community-dwelling people who are aged 65 or older (aged 60 or older if from a developing country);

- Studies approaching experiences of family caregivers in the process of providing care to older people in home environments;

- Studies that address older people's caregivers experience broadly.

The present synthesis did not include:

- Opinion-based studies/commentaries, literature reviews, study protocols and used mixed methods;

- Studies including mixed participants (e.g. caregivers, care receivers, and/or care professionals);

- Studies including caregivers no longer providing a primary caregiving role (such as older people who had already moved to long-term care facilities or had died when the studies were carried out);

- Studies including exclusively caregivers who cared for older people with specific clinical conditions;

- Studies focusing about caregivers' perspectives related to experiences with health systems, care transitions (such as discharge from hospitals), or clinical interventions to which care receivers were submitted.

\subsubsection{Study selection}

The articles identified in the search were grouped in Rayyan ${ }^{\circledR}$ software after the exclusion of duplicates. Using this tool allows reviewers to carry out the article inclusion steps simultaneously and with blinding (Ouzzani, Hammady, Fedorowicz, \& Elmagarmid, 2016). First, two reviewers (CPR and ASAS) read the titles and abstracts of all the articles identified in Rayyan ${ }^{\circledR}$. The discrepancies were sorted out by a third reviewer (MMGN) with the assistance of the software. After that, independent, thorough reading of the articles that met the eligibility criteria was performed to confirm the inclusion of these publications in the qualitative synthesis.

The objective of the present study was to address the experience of family caregivers in the process of providing care to older people who lived in communities. Family caregivers were defined as people of both genders, 18 years old or older, who had any degree of kinship with the older adults who received care, for example, spouses, siblings, children, children-inlaw, and grandchildren.

\subsubsection{Evaluation of the methodological quality of the included studies}

Evaluation of the quality of each publication included in the present study was carried out independently by two researchers and guided by the Critical Appraisal Skills Programme (CASP) (CASP, 2018). This is a checklist with ten items that address the following aspects: clarity and reach of objectives, method adequacy, sample, relationship between researchers and participants, data collection, data analysis, ethical aspects, data treatment, clarity of results, and importance of the contribution. The maximum score on this checklist is 10 points, and the higher the score, the higher the quality of the study. Articles that obtained a score lower than or equal to 5 points were excluded from the present qualitative synthesis.

\subsubsection{Data extraction and thematic analysis}

Data were extracted independently by two reviewers. The extraction was focused on the study characteristics: country of origin, objective, design, sample size, and data collection methods. For thematic analysis, data from the results sections of the selected publications were extracted. The texts of each study were organized and analyzed with the assistance of the QSR's 
Nvivo® software, which is designed for qualitative data analysis. Thematic analysis was carried out in three steps, as proposed by Thomas and Harden (2008):

- Step 1: The results of each study were codified line by line, and these codes were repeatedly examined and compared with those from the other studies;

- Step 2: The codes were related and grouped, originating descriptive themes, which were still close to the themes of the original studies;

- Step 3: The descriptive themes were examined repeatedly so the researchers could come up with more analytical themes by proposing interpretations and new constructs; in this step, the researchers went beyond the results of each included study and created the analytical themes of the present qualitative synthesis, directly addressing the experience of family caregivers in the process of providing care to older people.

Analytical themes emerged from this analysis and were then examined and validated by all the authors of the present synthesis.

\subsubsection{Evaluation of the level of confidence in the findings of the review}

The Confidence in the Evidence from Reviews of Qualitative Research (GRADE-CERQual) approach was used to evaluate the level of confidence in the evidence analyzed in the present review. This tool considers four components: 1) methodological limitations; 2) coherence; 3) data adequacy; and 4) data relevance (Colvin et al., 2018; Glenton et al., 2018; Lewin, Bohren, et al., 2018; Lewin, Booth, et al., 2018; Munthe-Kaas et al., 2018; Noyes et al., 2018).

The general confidence in the evidence that supports each analytical subject of the present review was assessed and classified as high, moderate, low, or very low. Initially, it was considered that all the findings could be classified as belonging to the high confidence category, and then the level of confidence was reduced when important concerns regarding any of the GRADE-CERQual components arose. These evaluations are shown in the table with the synthesis of qualitative findings of CERQual. The general confidence assessment for each finding and the explanation of this assessment were described in the table, which facilitates the use of the review findings in the decision-making process (Colvin et al., 2018; Glenton et al., 2018; Lewin, Bohren, et al., 2018; Munthe-Kaas et al., 2018; Noyes et al., 2018).

\section{Results}

The search process resulted in a total of 4,912 publications, which were evaluated in steps. Sixty-six publications were eligible for thorough reading, of which 18 met the inclusion criteria. The PRISMA flowchart is shown in Figure 1. 
Figure 1. PRISMA flowchart: study selection process for qualitative synthesis of evidence.
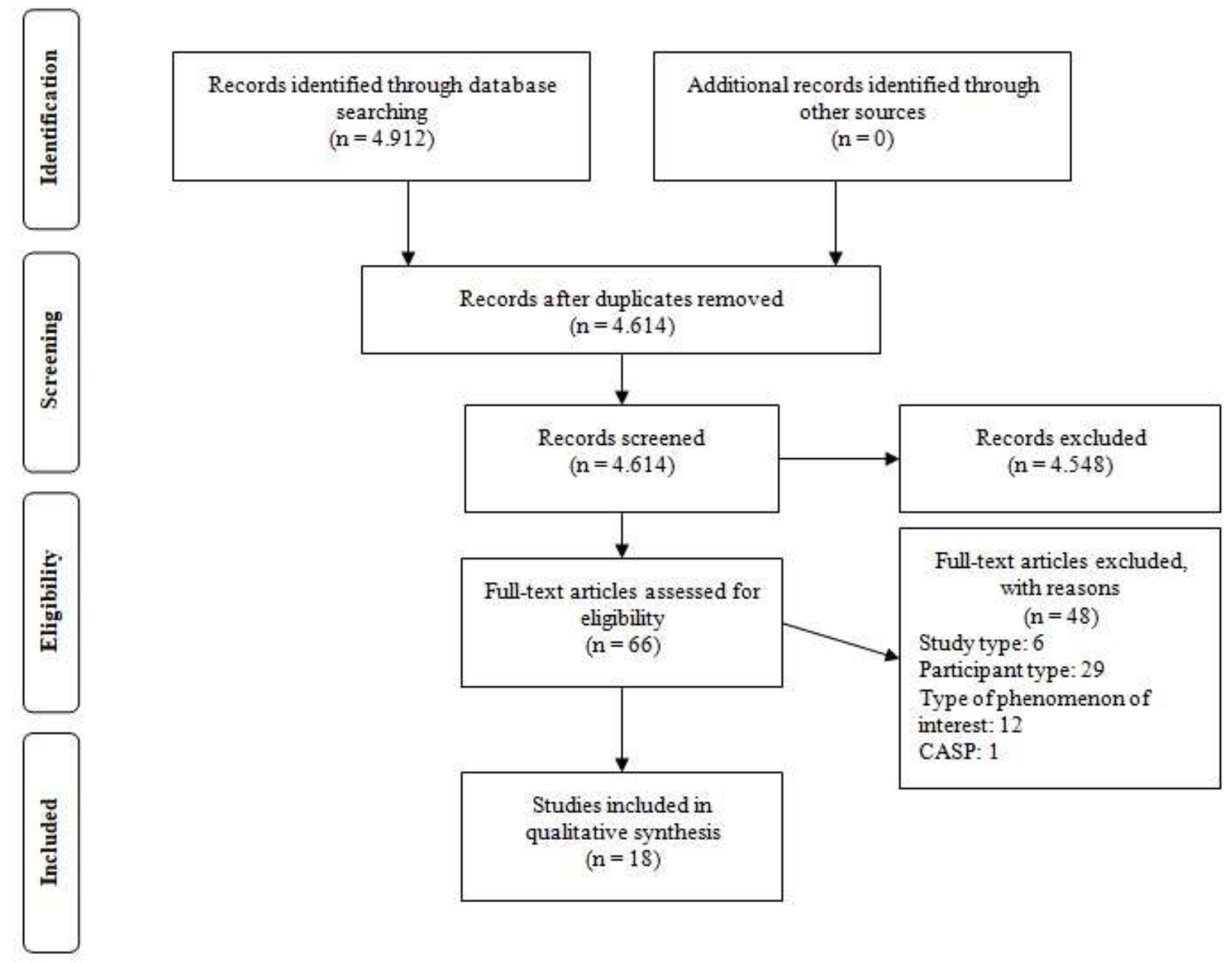

Source: Authors.

Data included 338 family caregivers in 11 countries were considered for analysis in the present study. The included studies were published from 1995 to 2019, with most being published in the past five years. Table 1 shows the main characteristics of the included studies and the evaluation of their methodological quality (CASP, 2018).

After the reading of the full papers and the generation of the initial codes from line-by-line codification, descriptive themes were extracted from the studies. Following this, in the final analytical step, three analytical themes were generated, which are represented in Figure 2: "Mixed feelings", "You have no life. Your own life gets put on hold.", and "The need for increasing coping strategies", with the latter split into two subthemes: "The need formal and informal support" and "Relying on spiritual guidance". The level of confidence found for each of the themes that emerged in the present qualitative synthesis was moderate to high (Table 2). In addition, Table 2 highlights the excerpts from the articles that illustrate the themes/subthemes that were developed in the present synthesis of evidence. 
Research, Society and Development, v. 10, n. 12, e27101220037, 2021

(CC BY 4.0) | ISSN 2525-3409 | DOI: http://dx.doi.org/10.33448/rsd-v10i12.20037

Table 1. Characteristics of the studies included and their methodological quality, according to criteria from the Critical Appraisal Skills Programme (CASP, 2018).

\begin{tabular}{|c|c|c|c|c|c|}
\hline Author/ Year/ Country & Objective of the study & Design & Sample & Methods & $\begin{array}{c}\text { CASP } \\
(10)\end{array}$ \\
\hline $\begin{array}{l}\text { Clark \& Huttlinger } \\
\text { (1998), United States }\end{array}$ & $\begin{array}{l}\text { To examine cultural factors, values, and beliefs that influence Mexican } \\
\text { American women to care for older family members and to investigate the } \\
\text { perceptions and experiences of these caregiving women. }\end{array}$ & Thematic analysis & $\begin{array}{l}8 \text { caregivers } \\
\text { (wives, daughters and } \\
\text { granddaughters) }\end{array}$ & $\begin{array}{l}\text { Semi-structured interviews; Analysis } \\
\text { guided by Ágar. }\end{array}$ & 7 \\
\hline $\begin{array}{l}\text { Garner \& Faucher (2014), } \\
\quad \text { United States }\end{array}$ & $\begin{array}{l}\text { To explore challenges and support experienced by family caregivers of } \\
\text { the older adult. }\end{array}$ & Photovoice & 5 caregivers & $\begin{array}{l}\text { Photos, contextualization of photos, } \\
\text { group meetings; } \\
\text { Analysis guided by Freire. }\end{array}$ & 10 \\
\hline Hashizume (2010), Japan & To explore the experiences of Japanese women caregiver's. & Grounded theory & $\begin{array}{l}11 \text { caregivers } \\
(6 \text { daughters and } 5 \\
\text { daughters-in-law) }\end{array}$ & $\begin{array}{l}\text { Interviews; } \\
\text { Analysis guided by Strauss and } \\
\text { Corbin. } \\
\end{array}$ & 8 \\
\hline $\begin{array}{l}\text { Horrel et al. (2015), New } \\
\text { Zealand }\end{array}$ & $\begin{array}{l}\text { To investigate the important health capabilities of people caring } \\
\text { informally for elders. }\end{array}$ & Thematic analysis & 60 caregivers & $\begin{array}{l}\text { Virtual forums; } \\
\text { Analysis based on Nussbaum's list of } \\
\text { essential human capabilities. }\end{array}$ & 8 \\
\hline Lane et al. (2003), Ireland & $\begin{array}{l}\text { To explore the perceived health and social care needs of family caregivers } \\
\text { of older people and to explore their experiences of home care. }\end{array}$ & Thematic analysis & 10 caregivers & $\begin{array}{l}\text { In-depth interviews, focus groups and } \\
\text { mail questionnaires; } \\
\text { Framework analysis (Ritchie and } \\
\text { Spencer). }\end{array}$ & 9 \\
\hline $\begin{array}{l}\text { Larrañaga et al. (2009), } \\
\text { Basco }\end{array}$ & $\begin{array}{l}\text { To deepen the understanding of the different strategies that women and } \\
\text { men take in their roles as caregivers through the interpretation and } \\
\text { analysis of their own perceptions. }\end{array}$ & Thematic analysis & $\begin{array}{l}37 \text { caregivers } \\
\text { (19 spouses, } 7 \text { sons/ } \\
\text { daughters, } 11 \text { other } \\
\text { relatives) }\end{array}$ & Focus groups. & 7 \\
\hline $\begin{array}{l}\text { Lewis et al. (1995), } \\
\text { United States }\end{array}$ & $\begin{array}{l}\text { To describe the experience of caregivers who resided with their elder } \\
\text { dependent parents and to discover the needs of caregivers. }\end{array}$ & Ethnography & $\begin{array}{l}5 \text { caregivers } \\
\text { (daughters) }\end{array}$ & $\begin{array}{l}\text { Interviews; } \\
\text { Analysis guided by Field and Morse. }\end{array}$ & 9 \\
\hline $\begin{array}{l}\text { Lopez-Hartmann et al. } \\
\text { (2016), Belgium }\end{array}$ & $\begin{array}{l}\text { To describe how adult daughters experience caring for a frail older parent } \\
\text { at home. }\end{array}$ & Phenomenology & $\begin{array}{l}11 \text { caregivers } \\
\text { (daughters) }\end{array}$ & $\begin{array}{l}\text { Open-ended interviews; } \\
\text { Analysis guided by interpretative } \\
\text { phenomenological analysis. }\end{array}$ & 10 \\
\hline $\begin{array}{l}\text { Mazza \& Lefevre (2005), } \\
\text { Brazil }\end{array}$ & $\begin{array}{l}\text { To investigate the daily life of family caregivers of elders and to } \\
\text { investigate this family caregiver, the act of caring, and how he/she sees } \\
\text { this older person receptor of his care. }\end{array}$ & $\begin{array}{l}\text { Collective Subject } \\
\text { Discourse }\end{array}$ & 17 caregivers & Semi-structured interviews. & 7 \\
\hline $\begin{array}{l}\text { McGarry \& Arthur } \\
\text { (2001), United } \\
\text { Kingdom }\end{array}$ & $\begin{array}{l}\text { To examine the experiences of informal caregivers who were aged } \\
75 \text { years and over. }\end{array}$ & Thematic analysis & $\begin{array}{l}14 \text { caregivers } \\
(1 \text { sister and } 13 \\
\text { spouses })\end{array}$ & $\begin{array}{c}\text { Interviews; } \\
\text { Analysis guided by Miles and } \\
\text { Huberman. }\end{array}$ & 10 \\
\hline
\end{tabular}


Research, Society and Development, v. 10, n. 12, e27101220037, 2021

(CC BY 4.0) | ISSN 2525-3409 | DOI: http://dx.doi.org/10.33448/rsd-v10i12.20037

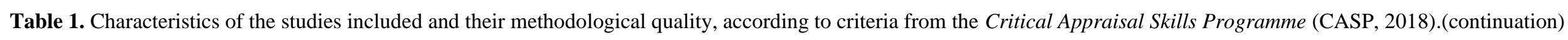

\begin{tabular}{|c|c|c|c|c|c|}
\hline $\begin{array}{c}\text { Author/Year/ } \\
\text { Country }\end{array}$ & Objective of the study & Design & Sample & Methods & $\begin{array}{c}\text { CASP } \\
\text { (10) }\end{array}$ \\
\hline $\begin{array}{l}\text { Moral-Fernández et al. } \\
\text { (2018), Spain }\end{array}$ & $\begin{array}{l}\text { To describe the initial process of individuals that become } \\
\text { caregivers of a dependent older relative. }\end{array}$ & Grounded Theory & $\begin{array}{l}11 \text { caregivers } \\
\text { (1 spouse, } 9 \text { sons/ } \\
\text { daughters and } 1 \\
\text { daughter-in-law) }\end{array}$ & $\begin{array}{l}\text { In-depth interviews; } \\
\text { Analysis guided by Glaser and } \\
\text { Strauss. }\end{array}$ & 10 \\
\hline $\begin{array}{l}\text { Paillard-Borg \& } \\
\text { Strömberg (2014), } \\
\text { Japan }\end{array}$ & $\begin{array}{l}\text { To describe the observations and thoughts in the experience of one } \\
\text { Japanese woman living with her older parents in the suburbs of } \\
\text { Tokyo }\end{array}$ & Content analysis & $\begin{array}{l}1 \text { caregiver } \\
\text { (daughter) }\end{array}$ & $\begin{array}{l}\text { Open-ended interview; } \\
\text { Analysis guided by Lundman \& } \\
\text { Hällgren-Graneheim. }\end{array}$ & 8 \\
\hline $\begin{array}{l}\text { Peacock et al. (2017), } \\
\text { Canada }\end{array}$ & $\begin{array}{l}\text { What is the experience of caregivers taking care of spouses with } \\
\text { multiple chronic conditions? }\end{array}$ & $\begin{array}{l}\text { Interpretive } \\
\text { description } \\
\text { approach }\end{array}$ & $\begin{array}{l}18 \text { caregivers } \\
\text { (spouses) }\end{array}$ & $\begin{array}{l}\text { Semi-structured interviews; } \\
\text { Analysis guided by Thorne. }\end{array}$ & 10 \\
\hline $\begin{array}{l}\text { Pedreira et al. (2018), } \\
\text { Brazil }\end{array}$ & To understand the lived experiences of older Brazilian caregivers. & Phenomenology & $\begin{array}{l}6 \text { caregivers } \\
(3 \text { spouses, } 2 \\
\text { daughters, } 1 \text { other } \\
\text { relative })\end{array}$ & $\begin{array}{l}\text { Semi-structured interviews; } \\
\text { Analysis guided by Heidegger. }\end{array}$ & 10 \\
\hline $\begin{array}{l}\text { Piercy (2007), United } \\
\text { States }\end{array}$ & $\begin{array}{l}\text { To describe the characteristics of strong commitment to home- } \\
\text { based elder care among intergenerational family caregivers. }\end{array}$ & Data analysis & $\begin{array}{c}66 \text { caregivers } \\
\text { (spouses, } \\
\text { grandchildren, } \\
\text { daughters and other } \\
\text { relatives) }\end{array}$ & $\begin{array}{l}\text { Semi-structured interviews; } \\
\text { Analysis guided by McCracken. }\end{array}$ & 9 \\
\hline $\begin{array}{l}\text { Rodger et al. (2015), } \\
\text { Ireland }\end{array}$ & $\begin{array}{l}\text { To explore the experiences of informal caregivers in Ireland and to } \\
\text { identify the support required to care for older adults at home. }\end{array}$ & Phenomenology & $\begin{array}{l}6 \text { caregivers } \\
\text { (1 wife, } 4 \text { daughters } \\
\text { and } 1 \text { sister })\end{array}$ & $\begin{array}{l}\text { Semi-structured interviews; } \\
\text { Analysis guided by Heidegger. }\end{array}$ & 9 \\
\hline $\begin{array}{l}\text { Six et al. (2019), } \\
\text { Belgium and Kenya }\end{array}$ & $\begin{array}{l}\text { To better understand how caregiving for older people has affected } \\
\text { family caregivers' lives and to compare the perspective of these } \\
\text { caregivers in Belgium and Kenya. }\end{array}$ & Phenomenology & $\begin{array}{l}30 \text { caregivers } \\
\text { (12 sons/ daughters; } \\
14 \text { sons/ daughters-in- } \\
\text { law; } 3 \text { other relatives) }\end{array}$ & $\begin{array}{l}\text { Semi-structured interviews; } \\
\text { Analysis guided by interpretative } \\
\text { phenomenological analysis. }\end{array}$ & 10 \\
\hline $\begin{array}{l}\text { Williams et al. (2016), } \\
\text { Canada }\end{array}$ & $\begin{array}{l}\text { How does social location influence the experience of family } \\
\text { caregivers of older adults with multiple chronic conditions? }\end{array}$ & Grounded Theory & $\begin{array}{c}40 \text { caregivers } \\
\text { (18 spouses, } 18 \\
\text { sons/daughters and } 4 \\
\text { other relatives) }\end{array}$ & $\begin{array}{l}\text { Semi-structured interviews; } \\
\text { Analysis guided by Charmaz. }\end{array}$ & 10 \\
\hline
\end{tabular}

Source: Authors. 


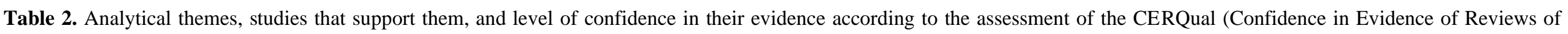
Qualitative Research).

\section{Themes: Mixed feelings}

\section{Citations of support}

"Yeah, you sort of...it's difficult to adjust to this change.... But you know, gradually over time you adjust and yeah, you know, learn to more or less deal with it ..." (Williams et al., 2016, p.8)

"I mean they're thankful for what I do, but I also feel like I also have them to thank for a lot of different things, so I kind of see it as like kind of giving back..." (Williams et al., 2016, p.12)

D1: They always took care of me when I was little, now it is my duty to give something back. (Lopez Hartmann et al., 2016, p.1695)

"I believe that we're to honor our parents and our grandparents, and in caring for them, we're honoring them." (Piercy, 2007, p.S383)

"I love them ...I don't know what I'd do with myself if something happened to them..." (Piercy, 2007, p. S383)

I sometimes wonder if what I have been doing by being the caregiver whether I am doing it out of a sense of duty or because of love. (Horrell et al., 2015, p.343)

"Yeah, yeah, like as I said the first part, the first few years, depression, you just feel guilt, you sort of feel you're giving up your whole life for them, everything stops, you feel resentment, you feel, oh, haven't I helped you enough in my life, financially and...” (Williams et al., 2016, p.7)

"So our relationship together has grown because we are able to spend a lot more quality time together and she has been able to see our family up close and personal." (...) "When you take care of someone, I think you learn to love them more..." (Piercy, 2007, p.S385)

"I think in my mind, always thinking about the past and all the crappy things that happened between us and all the crappy things that my mom did."(Williams et al., 2016, p.10)

My family at home suffers, like my son said to me the other day. He said 'I miss my mammy' ... because he was working shift work ... and I am gone the next morning when he gets in ... I would not see him, you are halved you know and that is what happens. (Rodger et al., 2015, p.282)

The only thing I can tell you about caregiving is that it is very confining - very, very, very confining, especially if the patient is accepting you for all his suport, whether it be his medical needs or his psychological needs... (MB Lewis et al., 1995, p.60)

"The need I have is for time outside doing ordinary things; people watching with a cup of coffee, watching a show and having a bit of a laugh and importantly all without any feelings of guilt and there lies the catch!!” (Horrell et al., 2015, p.344)

"I no longer have financial peace of mind or freedom to do activities I'd normally do". (Horrell et al., 2015, p.342) 


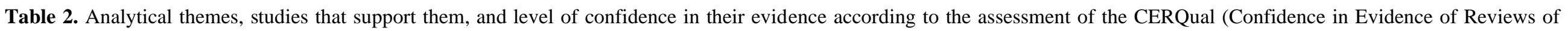
Qualitative Research). (continuation)

\section{Themes: "You have no life. Your own life gets put on hold."}

\begin{tabular}{|c|c|}
\hline Citations of support & $\begin{array}{l}\text { Studies that contributed with the themes and } \\
\text { level of confidence in the evidence }\end{array}$ \\
\hline $\begin{array}{l}\text { "You have no life. Your own life gets put on hold and the demands of this person get more and more as time goes by and so you have less and less to be } \\
\text { yourself" (Williams et al., 2016, p.7) } \\
\text { "I beliebe that God made women strong, (reaffirmation by the group), as we have a spirit of sacrifice, because they don't have" (Larrañaga et al., 2009, } \\
\text { p.52) } \\
\text { A son is different as a daughter. My brothers visit our parents every week. But doing the laundry, grocery shopping, cooking; that's my sister and me. } \\
\text { (Lopez Hartmann et al., 2016, p.1698) } \\
\text { "I feel like a mother kangaroo carrying her baby everywhere she goes. Her lifestyle revolves around her baby ... doing whatever she has to do." (Garner \& } \\
\text { Faucher, 2014, p.68-9) } \\
\text { "Time, time, time is what you lack. You don't have it. You have no time, and if he needs time, he gets it from you. If you have only a bit, you use that for } \\
\text { your husband. You are the one that doesn't have time" (Moral-Fernández et al, 2018, p.287) } \\
\text { "There are times when I feel like I cannot take it anymore, I need a break, it is like my life revolves around doing the very same things everyday-I } \\
\text { hardly have time for myself..." (Six et al., 2019, p.129) } \\
\text { "I started to live his life. I'm hypertensive. I control my diabetes, and it is always at the limit. I don't go to the doctor! If I do not take care of me, it is } \\
\text { over. I have paid for a tooth implant and I did not go have it done". (Pedreira et al., 2018, p.3318) } \\
\text { "As mean as this sounds, I am looking forward to what I call my next life. When I know I have looked after hubby and mum as long as it's needed, but }\end{array}$ & $\begin{array}{l}\text { High confidence: } \\
\text { Eight studies raise no concerns about coherence, } \\
\text { relevance, adequacy and methodologic limitations } \\
\text { (Garner \& Faucher, 2014; Horrell et al., 2015; Mb } \\
\text { Lewis et al., 1995; McGarry \& Arthur, 2001; } \\
\text { Peacock et al., 2017; Pedreira et al., 2018; Six et } \\
\text { al., 2019; Williams et al., 2016). } \\
\text { Two studies with moderate confidence due to } \\
\text { concerns about relevance (Moral-Fernández et al., } \\
2018 \text { ) and adequacy limitations (Hashizume, } \\
2010 \text { ). } \\
\text { One study with low confidence due to concerns } \\
\text { about coherence, relevance, adequacy and } \\
\text { methodological limitations (Larrañaga et al., } \\
\text { 2009). }\end{array}$ \\
\hline
\end{tabular}




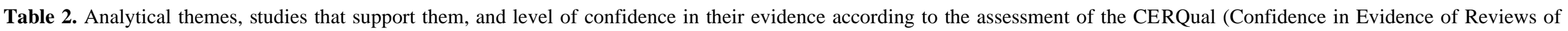
Qualitative Research). (continuation)

\begin{tabular}{|cc}
\hline Themes: The need for increasing coping strategies \\
Subthemes: The need formal and informal support
\end{tabular}

Citations of support

"Friends and family. Especially family. My brother and sister are here a lot and help out. We take turns." (MB Lewis et al., 1995, p.61)

"The doctors and staff have been faithful and supportive throughout our ordeal", and they "have always been there to serve our needs, both medically and emotionally." (Garner \& Faucher, 2014, p.70)

"I do not feel alone. I know that when I say that I do not feel well, others will take over the care for my mother." (Lopez Hartmann et al., 2016, p.1699)

"It is just me and my mother. Because no one wants to help. Everybody left when the illness came." (Pedreira et al., 2018, p.3320)

"Every day, I am the one who takes care of him. [...] there is no one else [...]. All the housework is done for me." (Pedreira et al., 2018, p.3318)

"I don't think it's asking too much for my brother to come get Daddy and let him stay him just one time a month. So it would be where I could just do something and not have to worry about it..." (MB Lewis et al., 1995, p.62)

"Her home help is an exceptional lady, she is as good as a tonic, she is wonderful to her, she is like one of the family" (Rodger et al., 2015, p.283)

"Regarding governmental responsibilities, caregivers believed they should "look after caregivers properly" since "caregivers are vulnerable and can feel very isolated." (Lane et al., 2003, p.145)

"So, if I knew that there was another source available to come in and stay a few hours and let me out that would help. I can hang on if I can get a little bit of a break" (MB Lewis et al., 1995, p.59)

\section{Subthemes: Relying on spiritual guidance}

\section{Citations of support}

Religion and/or spirituality provided comfort and meaning to life and assisted caregivers cope with caregiving stresses (...) "Spiritually I have a lot of faith and I've accepted that I've been chosen to do this and with God, I put God in front, first and foremost. I think that is what keeps me doing it and keeps me going" (Williams et al., 2016, p.12)

"My faith in God, my prayer life, the support of praying friends and people who really care for us, have kept us going." (Peacock et al., 2017, p.217) They say that God has united us. As the Bible says, He united two in one. What one feels the other feels, right? And the word of God, it is being fulfilled in our lives. And He is giving me strength. (Pedreira et al., 2018, p.3319)
Studies that contributed with the themes and level of confidence in the evidence Moderate confidence:

Seven studies raise no concerns about coherence, relevance, adequacy and methodologic limitations (Lane et al., 2003; Mb Lewis et al., 1995; Lopez Hartmann et al., 2016; Peacock et al., 2017; Pedreira et al., 2018; Rodger et al., 2015; Williams et al., 2016).

Three studies with moderate confidence due to concerns about relevance (Piercy, 2007; Six et al., 2019) and adequacy limitations (Garner \& Faucher, 2014).

Three studies with low confidence. Two raise concerns about coherence, and adequacy limitations (Hashizume, 2010; Mazza \& Lefevre, 2005). And one raises concerns about relevance, adequacy and methodologic limitations (Paillard-Borg \& Strömberg, 2014).

\section{Studies that contributed with the themes and} level of confidence in the evidence Moderate confidence:

Six studies with moderate confidence. Four raise concerns about adequacy limitations (Garner \& Faucher, 2014; Peacock et al., 2017; Pedreira et al. 2018: Williams et al.,2016). And two raise concerns about relevance and adequacy limitations (MoralFernández et al., 2018; Six et al., 2019).

Source: Authors. 
Figure 2. Representation of the experience of family caregivers in the process of providing care to older people.

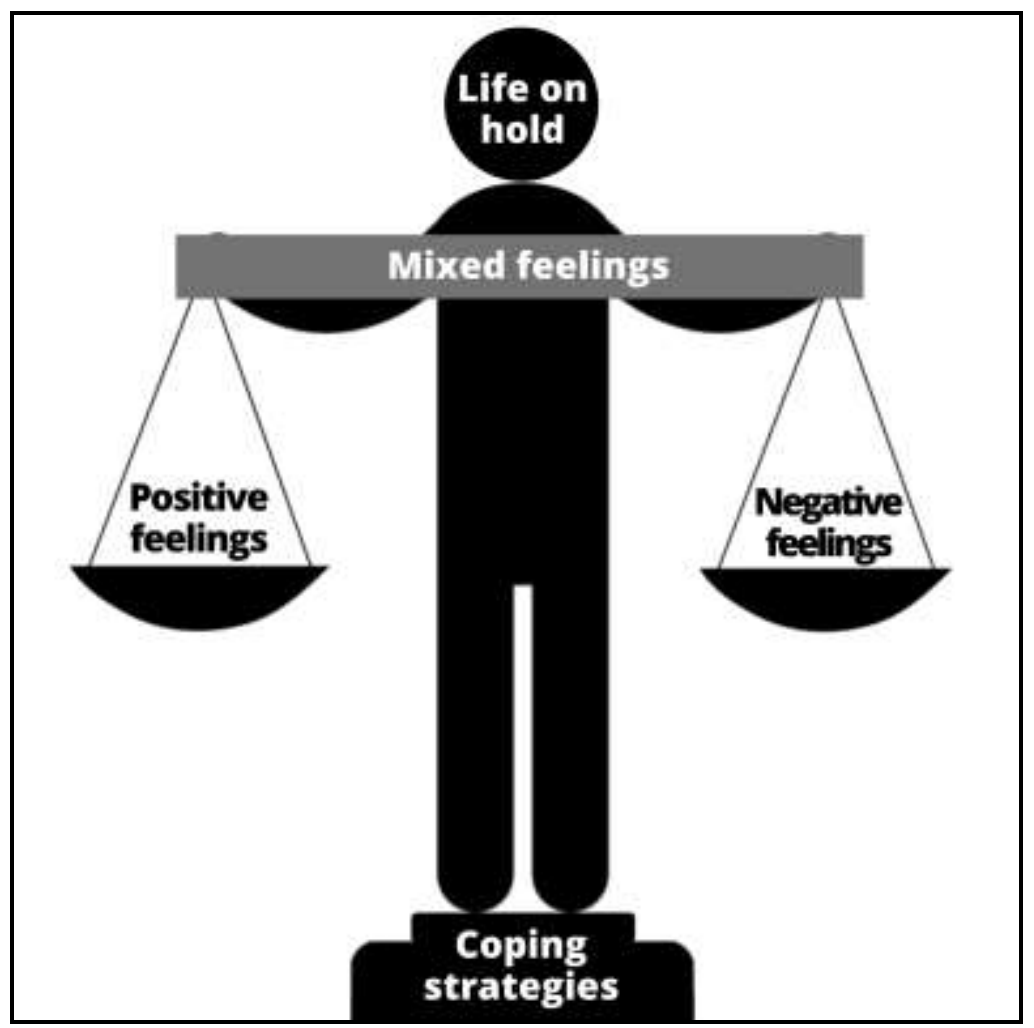

Source: Authors.

When observing the characteristics of the included studies presented in Table 1, it is noted that in most of them the data were collected through semi-structured interviews and were analyzed using different methodologies. In addition, it is important to emphasize that most of the included studies present high methodological quality.

After analyzing the texts of each included study through thematic analysis, three analytical themes emerged. In Table 2, some excerpts that support the analytical themes were listed. It also stands out that two of those themes -"mixed feelings" and "You have no life. Your own life gets put on hold." - had a high level of confidence; and the theme "The need for increasing coping strategies" showed moderate confidence. This level of confidence in the evidence was assessed using the GRADE-CERQual approach.

These themes were represented in Figure 2. The central theme identified in the present evidence synthesis was "life on hold", that shows when caregivers put care receivers at the center of attention, and end up putting their own lives on hold. This perception of "life on hold" reported by the caregivers was permeated by positive and negative feelings. Caregivers pointed out some coping strategies to try to reach a balance between providing care to older people and taking care of themselves. These coping strategies, namely formal and informal support and spirituality, were considered by caregivers as the main base to continued care provision. The three themes that emerged in this review are described below.

\subsection{Mixed feelings}

When older persons become dependent, their relatives have to organize to guarantee their well-being, which causes considerable changes in family dynamics (Lane et al., 2003; Moral-Fernández, Frías-Osuna, Moreno-Cámara, PalominoMoral, \& Del-Pino-Casado, 2018; Piercy, 2007). This process begins with uncertainty about what they will have to do when taking on the responsibility of providing care (Moral-Fernández et al., 2018; Williams et al., 2016), which is followed by 
multiple adaptations and the emergence of concerns about care (Moral-Fernández et al., 2018; Pedreira, Maria Cabral Ferreira, Tadeu Reis Silva, Maria de Oliveira Silva, \& Marques Freitas, 2018; Piercy, 2007; Williams et al., 2016). However, over time, caregivers develop normality and acceptance of their new situation (Clark \& Huttlinger, 1998; Moral-Fernández et al., 2018; Piercy, 2007; Williams et al., 2016), as shown in the study by Lane et al. (2003):

"The first two years were just... I nearly had a breakdown; I was a total wreck trying to come to terms with it... I would just cry (...) Now, I can deal with any situation, so it is not as bad as in the beginning." (Lane et al., 2003, p.144)

As the care process evolves over time, many caregivers mention a feeling of role reversal in family dynamics, with them becoming the parents of the care receivers (Clark \& Huttlinger, 1998; Garner \& Faucher, 2014; Lane et al., 2003; Lopez Hartmann et al., 2016; Rodger, Neill, \& Nugent, 2015; Williams et al., 2016). Consequently, the caregivers reported that they experienced mixed feelings regarding the act of providing care to older people (Clark \& Huttlinger, 1998; Hashizume, 2010; Horrell et al., 2015; M. B. Lewis, Curtis, \& Lundy, 1995; Moral-Fernández et al., 2018; Piercy, 2007; Six et al., 2019; Williams et al., 2016). They described positive emotions, such as feelings of satisfaction and reward (Lane et al., 2003; M. B. Lewis et al., 1995; Lopez Hartmann et al., 2016; Mazza \& Lefevre, 2005; Moral-Fernández et al., 2018; Peacock et al., 2017; Pedreira et al., 2018; Piercy, 2007; Six et al., 2019; Williams et al., 2016), as well as negative feelings, including anger, resentment, grief, sadness, and guilt (Clark \& Huttlinger, 1998; Garner \& Faucher, 2014; Hashizume, 2010; Horrell et al., 2015; Lane et al., 2003; Larrañaga et al., 2009; Rodger et al., 2015; Williams et al., 2016). It was found, however, that caregivers were more willing to describe positive emotions, to avoid hurting older people's feelings (Horrell et al., 2015; Peacock et al., 2017).

The sense of having a duty to provide care was mentioned in many of the studies, with ambiguous and complex interpretations. Some caregivers, for instance, reported that they considered the act of providing care to be a way of honoring their parents and grandparents (Clark \& Huttlinger, 1998; Hashizume, 2010; Piercy, 2007) and that they felt proud when they provided care (Mazza \& Lefevre, 2005; McGarry \& Arthur, 2001; Peacock et al., 2017; Williams et al., 2016). Doing it out of love for older people, because they were able to simply express affection and regard for their relatives, also emerged in several studies (Horrell et al., 2015; M. B. Lewis et al., 1995; Mazza \& Lefevre, 2005; McGarry \& Arthur, 2001; Moral-Fernández et al., 2018; Pedreira et al., 2018; Piercy, 2007; Six et al., 2019; Williams et al., 2016).

Other caregivers reported feelings about providing care to older people to reciprocate the care they received during childhood (Clark \& Huttlinger, 1998; Horrell et al., 2015; Lopez Hartmann et al., 2016; Mazza \& Lefevre, 2005; McGarry \& Arthur, 2001; Moral-Fernández et al., 2018; Six et al., 2019; Williams et al., 2016), and this repayment for care was surrounded by feelings of both gratitude (Clark \& Huttlinger, 1998; Horrell et al., 2015; Lane et al., 2003; Mazza \& Lefevre, 2005; Rodger et al., 2015; Six et al., 2019; Williams et al., 2016) and a sense of debt (Clark \& Huttlinger, 1998; Larrañaga et al., 2009; Lopez Hartmann et al., 2016; McGarry \& Arthur, 2001; Moral-Fernández et al., 2018).

The "duty of care" also assumed a negative interpretation in some studies (Hashizume, 2010; Horrell et al., 2015; Larrañaga et al., 2009; Moral-Fernández et al., 2018; Peacock et al., 2017; Piercy, 2007; Six et al., 2019; Williams et al., 2016). In some circumstances, the caregivers emphasized marital or filial obligations that compelled them to provide care (Horrell et al., 2015; McGarry \& Arthur, 2001; Moral-Fernández et al., 2018; Piercy, 2007; Six et al., 2019; Williams et al., 2016). In the study by Williams et al. (2016), a caregiver pondered:

"Well, you know, the marriage vows we took were, you know, said in sickness and in health, until death do us part. 
So, when problems come up, you deal with them, you know? And you find the best solution you can. That's just the way it is." (Williams et al., 2016, p.11)

The act of providing care and its development was pointed out ambiguously as a potential opportunity for both appeasement and aggravation of family conflicts. Regarding this question, for some caregivers, the act of providing care precluded the resolution of problems related to living together, which led them to emphasize care as a strict duty and a debt to the older person (Hashizume, 2010; Piercy, 2007; Williams et al., 2016). In contrast, in other cases, providing care allowed caregivers and older people to come together (Piercy, 2007; Williams et al., 2016), even when they had had issues interacting with each other throughout their lives (Piercy, 2007).

Positive family bonds were reinforced by some caregivers, who declared that the act of providing care gave meaning to their lives (Pedreira et al., 2018). This is illustrated by an excerpt from the report of a caregiver, transcribed in the study by Piercy (2007): "I love them... I don't know what I'd do with myself if something happened to them, how I'd fill my days."

Regardless of the feelings surrounding the duty of providing care to older people, caregivers often mentioned the burden of having to make decisions, manage adverse conditions, and guarantee proper care (Garner \& Faucher, 2014; Horrell et al., 2015; Lane et al., 2003; M. B. Lewis et al., 1995; Lopez Hartmann et al., 2016; McGarry \& Arthur, 2001; MoralFernández et al., 2018; Peacock et al., 2017; Piercy, 2007; Rodger et al., 2015; Williams et al., 2016). This can be observed in the report of a caregiver examined in the study by Peacock et al. (2017): "Equality is gone... it's not just doing it, physically doing it, it's the decisions".

The care receivers, in addition to losing their autonomy, often have multiple chronic conditions that require monitoring (Williams et al., 2016). However, caregivers stressed that they did not feel secure about whether the older people were being appropriately cared for (Garner \& Faucher, 2014; Lane et al., 2003; Lopez Hartmann et al., 2016; McGarry \& Arthur, 2001; Peacock et al., 2017; Williams et al., 2016). The findings by Garner and Faucher (2014) corroborate these concerns, indicating that caregivers have to guarantee that the actions of the different specialists who provide professional care to older people are in harmony, the medications taken by the care receivers will not lead to undesirable drug interactions, and the use of equipment such as walkers is correct.

In face of these concerns, Lane et al. (2003) emphasized the need to train and guide caregivers, which can be exemplified by the following report: "There is always danger with tablets; if you got a bit of guidance it would help". At the same time, clinical management strategies oriented toward caregivers proved to be important, given that, because caregivers assumed the responsibility of providing care, often without the help of other people, they reported that they experienced overload and the development of their own health problems (Hashizume, 2010; Horrell et al., 2015; Larrañaga et al., 2009; Lopez Hartmann et al., 2016; McGarry \& Arthur, 2001; Moral-Fernández et al., 2018; Paillard-Borg \& Strömberg, 2014; Peacock et al., 2017; Williams et al., 2016).

Another important point reported by caregivers was related to the financial difficulties resulting from direct expenses related to older people's health or the danger of not being able to keep their job (Garner \& Faucher, 2014; Hashizume, 2010; Horrell et al., 2015; Moral-Fernández et al., 2018; Six et al., 2019). In addition to the challenges of balancing care and work, caregivers mentioned difficulty finding time for personal activities (Hashizume, 2010; Pedreira et al., 2018; Williams et al., 2016), which aggravated either feelings of progressive isolation (Lane et al., 2003; Moral-Fernández et al., 2018; Peacock et al., 2017; Six et al., 2019; Williams et al., 2016) or a sense of guilt when they opted to enjoy social life opportunities and leave the older person at home (Hashizume, 2010; Horrell et al., 2015; Lewis et al., 1995; Lopez Hartmann et al., 2016; McGarry \& Arthur, 2001; Peacock et al., 2017; Rodger et al., 2015; Six et al., 2019; Williams et al., 2016). 
Consequently, caregivers put their own lives on hold to guarantee proper care to older people, because the needs and feelings of the person who was being assisted came first (Horrell et al., 2015; McGarry \& Arthur, 2001).

\section{2 "You have no life. Your own life gets put on hold."}

Several caregivers experienced the feeling of having their lives put on hold, and the more dependent older people got, the longer it took them to carry out the activities. Consequently, the more the caregivers' lives were left aside (Garner \& Faucher, 2014; Horrell et al., 2015; Larrañaga et al., 2009; Peacock et al., 2017; Pedreira et al., 2018; Rodger et al., 2015; Six et al., 2019; Williams et al., 2016). Corroborating this, a caregiver who provided care to her mother and her husband said:

"As mean as this sounds, I am looking forward to what I call my next life. When I know I have looked after hubby and mum as long as it's needed, but when they are gone, I will have my life. I'm going to be totally selfish and look after me... it will be very strange to me too, cos all my life I have looked after others. It's what keeps me going some days." (Horrell et al., 2015, p. 345)

The "life on hold" feeling proved stronger in women, to whom the responsibility for care is usually assigned (Hashizume, 2010; Larrañaga et al., 2009; Lopez Hartmann et al., 2016; Paillard-Borg \& Strömberg, 2014; Williams et al., 2016). They often expressed early acceptance by "automatically" assuming care of their older parents (Paillard-Borg \& Strömberg, 2014) and got much more involved with the act of providing care than men (Hashizume, 2010; Larrañaga et al., 2009; Lopez Hartmann et al., 2016; McGarry \& Arthur, 2001; Paillard-Borg \& Strömberg, 2014; Peacock et al., 2017; Williams et al., 2016).

The findings of McGarry and Arthur (2001) and Peacock et al. (2017) pointed to changes in the traditional routine attributed to the female gender because of the dependence of care receivers. In addition to their everyday activities, women began to deal with finances and home maintenance, while men began doing household chores (McGarry \& Arthur, 2001; Peacock et al., 2017). Regardless of gender, however, all the caregivers had to adapt to a different routine to carry out care (Garner \& Faucher, 2014; Horrell et al., 2015; Lane et al., 2003; Larrañaga et al., 2009; Peacock et al., 2017; Rodger et al., 2015; Six et al., 2019; Williams et al., 2016).

Many abandoned their daily lives and stopped working and interacting with friends and relatives (Garner \& Faucher, 2014; Horrell et al., 2015; Larrañaga et al., 2009; Peacock et al., 2017; Six et al., 2019; Williams et al., 2016). Others had double or triple shifts of activities, because they balanced their personal and professional life with the act of providing care (Garner \& Faucher, 2014; Hashizume, 2010; Lopez Hartmann et al., 2016; Rodger et al., 2015; Six et al., 2019; Williams et al., 2016). A caregiver who participated in the study by Lewis et al. (1995) reported: "It is very confining. I can't leave my dad for a minute unless he is being cared for."

Most importantly, there was the difficulty of managing time spent on the care of the older person and time dedicated to themselves (Garner \& Faucher, 2014; Larrañaga et al., 2009; Pedreira et al., 2018; Rodger et al., 2015; Six et al., 2019; Williams et al., 2016), as illustrated by the account of a participant:

"You have no life. Your own life gets put on hold and the demands of this person get more and more as time goes by and so you have less and less time to be yourself." (Williams et al., 2016, p. 10-1)

Caregivers often expressed a feeling of overload (Hashizume, 2010; Larrañaga et al., 2009; Lopez Hartmann et al., 2016; McGarry \& Arthur, 2001; Moral-Fernández et al., 2018; Paillard-Borg \& Strömberg, 2014; Peacock et al., 2017; Williams et al., 2016), which directly interfered with both their physical and mental condition (Larrañaga et al., 2009; McGarry 
\& Arthur, 2001; Peacock et al., 2017; Pedreira et al., 2018; Williams et al., 2016). Caregivers revealed that they could have reached a balance between the care provided and the management of their personal and professional life if they had had the help of other people during the process (Williams et al., 2016).

\subsection{The need for increasing coping strategies}

The demand for care of older people tends to increase gradually, and caregivers reported that they took on this responsibility alone, incrementally, unconsciously, and automatically (Hashizume, 2010; Lopez Hartmann et al., 2016). Faced with this situation, over time, caregivers began to realize their overload and incorporate some coping strategies to keep providing care to older people without compromising their physical and emotional health, as well as having some time to take care of themselves (M. B. Lewis et al., 1995; Pedreira et al., 2018; Six et al., 2019; Williams et al., 2016). In the present qualitative evidence synthesis, the need for both formal and informal support and spirituality emerged as coping strategies.

\subsubsection{The need formal and informal support}

In the present study, informal support was considered to be support offered by relatives, friends, and neighbors to the main caregivers, whereas formal support was defined as assistance given by the health professionals who helped care receivers.

Caregivers performed care-related activities by themselves, either because they did not want to compromise the routines of other people (Hashizume, 2010; Williams et al., 2016), or because other family members did not get involved with the care process effectively (Horrell et al., 2015; Mazza \& Lefevre, 2005; Pedreira et al., 2018). However, as time went by, they realized that they needed help, they needed to take care of themselves and rest (Lane et al., 2003; M. B. Lewis et al., 1995; Pedreira et al., 2018; Six et al., 2019; Williams et al., 2016), as exemplified by the following report from the study by Williams et al. (2016): "I think perhaps one of the things that's changed from when I first started to now is that I realized that I can't do it all..."

Caregivers reported that they had an interest in engaging in pleasant activities such as doing physical exercises or having coffee with their friends, but to do so, they would need support for the care process that made that respite feasible (Lane et al., 2003; M. B. Lewis et al., 1995; Peacock et al., 2017; Williams et al., 2016). Although the main caregivers were aware of the need for support, in many cases, not enough was offered to them (Horrell et al., 2015; Lane et al., 2003; M. B. Lewis et al., 1995; Lopez Hartmann et al., 2016; Mazza \& Lefevre, 2005; McGarry \& Arthur, 2001; Peacock et al., 2017; Piercy, 2007; Six et al., 2019). In other circumstances, when caregivers delegated the act of providing care to a professional or relative, they remained the main caregivers, responsible for coordinating care, which meant that even with formal and/or informal support, caregivers still had to fully manage care (Lopez Hartmann et al., 2016).

However, it was found in some studies that care receivers themselves hindered this support by not being willing to accept care from anyone except the main caregivers (Lane et al., 2003; Lopez Hartmann et al., 2016). Lane et al. (2003) suggested the following explanation to justify such behavior:

"When they were growing up, all the elderly had no care except from the family... there was no such thing as respite care or social services ... they are all alien things to those (older) people, intruders into their world." (Lane et al., 2003, p.145)

Lopez Hartmann (2016) reported that care receivers accepted support from relatives more easily. Caregivers avoided obtaining help from external professionals in order not to go against the wishes of their parents, and this support was solicited only when it was considered unavoidable. As a consequence, in most studies, support offered by relatives and friends was one 
of the foundations of caregivers' maintenance and balance in face of the need to provide care to themselves and older people (Lane et al., 2003; M. B. Lewis et al., 1995; Lopez Hartmann et al., 2016; Paillard-Borg \& Strömberg, 2014; Peacock et al., 2017; Pedreira et al., 2018; Piercy, 2007; Rodger et al., 2015; Six et al., 2019).

In contrast, caregivers mentioned that formal support was an important aid (Peacock et al., 2017; Pedreira et al., 2018; Six et al., 2019; Williams et al., 2016), given that it allowed them to keep their role as caregivers and have control over their lives (Lane et al., 2003). However, they stated that getting this support was a big challenge (Lane et al., 2003; M. B. Lewis et al., 1995; Peacock et al., 2017; Rodger et al., 2015; Six et al., 2019; Williams et al., 2016).

Daycare centers and home care programs were considered invaluable resources by them, because they could carry out their activities without worrying (Garner \& Faucher, 2014; M. B. Lewis et al., 1995; Peacock et al., 2017; Rodger et al., 2015). Additionally, these home support centers could contribute to promoting health education by providing caregivers with training (Williams et al., 2016).

\subsubsection{Relying on spiritual guidance}

Spirituality also emerged as a caregivers' coping strategy (Garner \& Faucher, 2014; Moral-Fernández et al., 2018; Peacock et al., 2017; Pedreira et al., 2018; Six et al., 2019; Williams et al., 2016). It was observed that this strategy was developed by caregivers so they could deal with stress related to providing care (Garner \& Faucher, 2014; Moral-Fernández et al., 2018; Pedreira et al., 2018; Six et al., 2019; Williams et al., 2016), in addition to offering comfort and meaning in their lives in face of their demanding care routine (Garner \& Faucher, 2014; Pedreira et al., 2018; Williams et al., 2016). This can be illustrated by the report of a caregiver:

"Spiritually. I have a lot of faith and I've accepted that I've been chosen to do this and with God, I put God in front, first and foremost. I think that is what keeps me doing it and keeps me going." (Williams et al., 2016, p. 12)

Faith and participation in activities at church also helped caregivers to keep playing their role (Garner \& Faucher, 2014; Peacock et al., 2017; Pedreira et al., 2018; Six et al., 2019; Williams et al., 2016). For instance, one of the caregivers analyzed in the study by Peacock et al. (2017) stated: "You know, church has been a major part of our lives."

\section{Discussion}

The present synthesis of evidence covered the experience of family caregivers in the face of the process of providing care to dependent older people, with the objective of better understanding this phenomenon broadly; that is, studies that did not focus in care receivers with specific clinical conditions. The perception of "life on hold" reported by the caregivers stood out as an important finding in the present study, and this experience was permeated by positive and negative feelings. Caregivers pointed out some coping strategies as a way to try to reach a balance between providing care to themselves and older people, namely formal and informal support and spirituality.

The feelings experienced by the caregivers analyzed in the studies included in the present synthesis showed that the relationship between caregivers and care receivers is intense and complex. Regardless of the nature of the feelings reported by caregivers, that is, whether the sensation was positive or negative, it was noticed that care activities resulted in emotional discomfort for caregivers. Care-related tasks are physically exhausting and emotionally demanding, and these circumstances may lead to negative psychological effects and higher risks of overload for caregivers (Maree, Moshima, Ngubeni, \& Zondi, 2018; McCabe et al., 2016; Moral-Fernández et al., 2018; Vallée \& Vallée, 2017; WHO, 2017; Woodford, Farrand, Watkins, 
\& LLewellyn, 2018).

The central theme identified in the present evidence synthesis was life on hold. This theme has also emerged in other qualitative studies that have addressed the experience of caregivers who provided care to patients with terminal illnesses (E. T. Lewis et al., 2019) and cancer (Goldblatt, Granot, \& Zarbiv, 2019; Maree et al., 2018).

Formal and informal support stood out among the coping strategies found in the selected publications. This strategy must be considered when improving the process of providing care to older people in the home environment. Thus, it is necessary to elucidate strategies described in the literature to improve the caregiver's routine. In addition to promoting more research that points out which strategies are efficient to ensure the well-being and quality of life of family caregivers.

In this sense, it is indispensable that health professionals understand the family context in which care receivers are inserted and the experiences of caregivers, to promote comprehensive care for older people and all their relatives. It is important to emphasize that family caregivers are important actors in home care, and that it is crucial that health professionals evaluate whether caregivers are overloaded, socially isolated, or showing symptoms of depression and emotional discomfort as a consequence of the act of providing care. Therefore, when assisting the older people, health professionals should also assess the clinical conditions of the caregivers and check if they have experienced negative feelings, such as anger, resentment, grief, sadness, and guilt, and if so, it is recommended to encourage the caregivers to look for psychological counseling to prevent the development of mental disorders.

However, a study by McGarry and Arthur (2001, p.187) includes the testimony of a caregiver who reported feeling ignored during the appointments: "If we're both all right then we get through, but we'd like to find someone who was interested in us... to see if we're all right." It can be noticed that the caregiver felt neglected by the health system and professionals, who focused their attention mostly to the older person who received the care. However, it is also imperative to pay attention to caregivers' health, given that their routines can lead to the development of diseases.

Caregivers, in taking up their caregiver role, also say that they put care receivers at the center of attention, which made them put their own lives on hold. This means that they not only stop going out and having fun, but also neglect their selfcare, for example, stopping visits to their doctor or dentist and doing physical exercise (Peacock et al., 2017). Thus, health professionals must accompany caregivers and make sure that all their health conditions are being treated, since it is known that psychological aspects can trigger and/or aggravate the symptoms of some health conditions.

The Burden Interview can be used to assist healthcare professionals in assessing caregiver burden. This scale was developed to assess the caregiver burden of older adults with dementia, however it has been used for other types of caregivers, because it includes comprehensive items that address dimensions common to various mental and physical diseases. The 22 scale's items reflect respondent's areas of concern such as: health, social and personal life, financial situation, emotional well being and interpersonal relationships (Scazufca, 2002).

The present review also revealed that caregivers felt insecure regarding the care provided to the older adults, especially when it comes to making decisions, managing adverse conditions and ensuring adequate care. Such findings also emerged in other researches involving caregivers (Lawrence, Murray, Samsi, \& Banerjee, 2008; Maree et al., 2018; McCabe et al., 2016). An initiative to minimize this insecurity is to develop the practice of patient-centered care in a way that, in addition to involving the older adults, when they are in clinical conditions to do so, the health professionals also include their caregivers. For this end, a care plan and decision making shared with the older people and caregivers must be adopted, making sure that they are active partners, and, therefore, making caregivers feel safer and more engaged in the care process for the older people (Bombard et al., 2018; Holroyd-Leduc et al., 2016).

In addition, health professionals must ensure that the care offered by informal caregivers is properly executed. To do 
that, when necessary, health professionals must train caregivers in developing their activities, ensuring that older people are well cared for. It is necessary to emphasize that the training sessions bring clarity to the caregivers about what their duties and responsibilities are in relation to care, and it also contributes to mediate a key barrier identified: providers' skepticism towards engaging patients and caregivers and empowering them. Therefore, these training sessions help to create a level playing field and support staff in their efforts to be partners (Bombard et al., 2018).

The present review reveals that caregivers reported the need for formal and informal support, as coping strategies. However, which services they considered sufficient to guarantee such support have not been so well elucidated. Given this, the reflection goes through whether the caregivers are clear about what could be done to improve their condition as caregivers. Corroborating this reflection, a qualitative study described that it is unclear whether caregivers do not discuss their specific needs because they do not know how to express themselves or because they regard looking after care receivers as their natural duty and therefore do not perceive their own needs (Furlong \& Wuest, 2008). This should be further elucidated in other qualitative studies.

Even though care providers did not point out specific measures that could be provided in order to support them, it is indispensable to promote public policies such as the provision of home care, daycare centers, support groups, and other strategies. Mbanaso, Shavelson and Ukawuilulu (2006) emphasized that, in addition to these strategies, actions that decrease caregivers' level of isolation by means of local support and remote assistance must be promoted.

In this review, one unique finding that is not deeply explored elsewhere is care receivers themselves hindered this support by not being willing to accept care from anyone except the main caregivers. Therefore, for the coping strategies to be successful, it is essential that the care receivers are made aware of the importance of the caregiver sharing care with other family members, as well as with formal care services such as daycare and home care.

In this sense, a substantive grounded theory was developed to describe the process of deciding to use home healthcare services (HHCS). This process consisted of three stages: first, including initial resistance, especially by older adults; then caregivers' trying to do too much without help; and finally, families' giving HHCS a try; accommodating the use of HHCS, especially if the older adults developed a personal relationship with the HHCS worker (Crist, García-Smith, \& Phillips, 2006). In order to enhance acceptability of HHCS, it is recommended that at the individual level, health professionals taking the time to establish trust by giving personal attention, this is essential. At the system level, the HHCS agency needs to try to assign the same nurse and other staff to make consistent visits. Because, the opportunity to see the same nurse more than once facilitates relationship building (Crist \& Speaks, 2011).

It is believed that the findings of the present qualitative synthesis can provide resources for discussions about the experience of family caregivers. These findings can also contribute to the creation of public policies that allow caregivers to provide care to their relatives and themselves, including the emotional support necessary for their mental health not to be compromised by care routines, resulting in improvements in their quality of life.

\subsection{Strengths and limitations}

Although the search strategy was comprehensive, only articles published in English, Spanish, and Portuguese were selected for full-text reading. Some included studies provided limited information, derived from superficial and descriptive data. Another problem was that some publications did not indicate the age, degree of kinship with the care receiver, or gender of caregivers. These issues hindered a more comprehensive analysis of the influence of these factors on the findings of the present synthesis.

However, even with these limitations, the present study has high scientific pertinence because, to the best of the 
authors' knowledge, a synthesis of evidence has not yet been published that analyzed the experience lived by family caregivers of the older person in a holistic way, with the potential to reveal the experience lived by the caregivers, regardless of the clinical condition of the care receiver and thus emerge the possible demands that these caregivers present.

Additionally, the present synthesis was conducted according to the ENTREQ reporting guidelines. This checklist stands out because of its methodology for adopting sound strategies for data collection, analysis, and extraction. The article search and selection followed the PRISMA prerequisites, which emphasize the importance of describing the search strategy and the eligibility criteria, which allows for reproducibility of the study. The CASP checklist was used to evaluate which articles had higher and lower methodological quality. It is worth stressing that these steps were carried out by two researchers, who performed the assessment simultaneously and with blinding, and that the discrepancies were subsequently sorted out by a third reviewer.

It is important to emphasize that the findings of the present synthesis were obtained by applying thematic analysis, as proposed by Thomas and Harden (2008). It brings together and integrates the results of qualitative articles in a well-defined and transparent way, which leads readers to an understanding of the process of generation of the analytical themes. These themes emerge from third-party interpretations, which bring together and show primary study data beyond what they describe, yet respect and preserves their context and complexity. At the same time, the GRADE-CERQual systematic approach, developed in collaboration with and following the GRADE work group, was used to assess the level of confidence to be ascribed to these themes.

The authors believe that the results of the present metasynthesis will be important in providing public policymakers with resources to develop policies that are more humanized, aiming to improve the quality of life of caregivers and raise awareness of health professionals, managers, and relatives regarding the routine of main caregivers.

\section{Conclusion}

Several conflicting feelings emerged in the process of care, showing the complexity of the caregivers' condition. Many provided care out of love, reciprocity, and gratitude, while others considered that they did it out of obligation, in addition to expressing negative feelings such as resentment, anger, sadness, and grief. Regardless of their feelings, caregivers put their lives on hold in favor of care. However, they sought balance between providing care to the older person and themselves by applying coping strategies, including formal and informal support and spirituality.

Therefore, when confronted with the experience of family caregivers, health professionals will be able to be better prepared to provide older people and their relatives with comprehensive care. Additionally, policymakers must include these actors in public policies oriented toward older people to ensure that caregivers do not compromise their own lives and health in favor of taking care of others.

These study findings demonstrate the need for future interventional studies that propose strategies to minimize caregiver burden as well as emotional discomfort as a consequence of care provision. In addition, there is also a need to develop strategies to make the population aware of the importance of this care for the older person not only being provided by family caregivers, so that future recipients of care accept that their care is provided not only by family members but also by formal care services such as daycare and home care. Another point that is not well elucidated in the literature and that should be addressed in future qualitative research is the need to identify which specific supports caregivers need when assuming their role as caregivers. This results from the fact that it is not clear whether caregivers do not discuss their specific needs because they do not know how to express themselves or because they consider the act of caring as their natural duty and, therefore, do 
not realize their own needs

\section{Acknowledgments}

The authors wish to acknowledge the Federal University of Minas Gerais, for the financial support.

\section{References}

*Included articles in this qualitative synthesis.

Barnett-Page, E., \& Thomas, J. (2009). Methods for the synthesis of qualitative research: a critical review. BMC Medical Research Methodology, 9(1), 59.

Bombard, Y., Baker, G. R., Orlando, E., Fancott, C., Bhatia, P., Casalino, S., Onate, K., Denis, J., \& Pomey, M. (2018). Engaging patients to improve quality of care: a systematic review. Implementation Science: $I S, 13(1), 98$.

Booth, A. (2016). Searching for qualitative research for inclusion in systematic reviews: a structured methodological review. Systematic Reviews, 5(1), 74.

Cabote, C. J., Bramble, M., \& McCann, D. (2015). Family caregivers' experiences of caring for a relative with younger onset dementia: a qualitative systematic review. Journal of Family Nursing, 21(3), 443-468.

CASP (2018). Critical Appraisal Skills Programme- CASP. Qualitative studies checklist. https://casp-uk.net/casp-tools-checklists/ [Accessed January 10, $2021]$.

* Clark, M., \& Huttlinger, K. (1998). Elder care among mexican american families. Clinical Nursing Research, 7(1), 64-81.

Colvin, C. J., Garside, R., Wainwright, M., Munthe-Kaas, H., Glenton, C., Bohren, M. A., Carlsen, B., Tunçalp, O., Noyes, J., Booth, A., Rashidian, A., Flottorp, S., \& Lewin, S. (2018). Applying GRADE-CERQual to qualitative evidence synthesis findings-paper 4: how to assess coherence. Implementation Science, 13(S1), 13

Crist, J. D., García-Smith, D., \& Phillips, L. R. (2006). Accommodating the stranger en casa: how mexican american elders and caregivers decide to use formal care. Research and Theory for Nursing Practice, 20(2), 109-126.

Crist, J. D., \& Speaks, P. (2011). Keeping it in the family: when mexican american older adults choose not to use home healthcare services. Home Healthcare Now, 29(5).

Del-Pino-Casado, R., Rodríguez-Cardosa, M., López-Martínez, C., \& Orgeta, V. (2019). The association between subjective caregiver burden and depressive symptoms in carers of older relatives: a systematic review and meta-analysis. PloS One, 14(5), e0217648.

Domingues, N. S., Verreault, P., \& Hudon, C. (2018). Reducing burden for caregivers of older adults with mild cognitive impairment: a systematic review. American Journal of Alzheimer's Disease and Other Dementias, 33(7), 401-414.

Furlong, K. E. \& Wuest, J. (2008). Self-care behaviors of spouses caring for significant others with Alzheimer's disease: the emergence of self-care worthiness as a salient condition. Qualitative Health Research, 18(12), 1662-1672.

* Garner, S. L., \& Faucher, M. A. (2014). Perceived challenges and supports experienced by the family caregiver of the older adult: a photovoice study. Journal of Community Health Nursing, 31(2), 63-74.

Ge, L. \& Mordiffi, S. Z. (2017). Factors associated with higher caregiver burden among family caregivers of elderly cancer patients: a systematic review. Cancer Nursing, 40(6), 471-478.

Glenton, C., Carlsen, B., Lewin, S., Munthe-Kaas, H., Colvin, C. J., Tunçalp, Ö., Bohren, M. A., Noyes, J., Booth, A., Garside, R., Rashidian, A., Flottorp, S., \& Wainwright, M. (2018). Applying GRADE-CERQual to qualitative evidence synthesis findings-paper 5: how to assess adequacy of data. Implementation Science, 13(S1), 14.

Goldblatt, H., Granot, M., \& Zarbiv, E. (2019). "Death lay here on the sofa": Reflections of young adults on their experience as caregivers of parents who died of cancer at home. Qualitative Health Research, 29(4), 533-544.

Greenwood, N., \& Smith, R. (2015). Barriers and facilitators for male carers in accessing formal and informal support: A systematic review. Maturitas, 82(2), $162-169$.

Greenwood, N., \& Smith, R. (2016). The oldest carers: A narrative review and synthesis of the experiences of carers aged over 75 years. Maturitas, 94, 161172.

* Hashizume, Y. (2010). Releasing From the Oppression: Caregiving for the elderly parents of japanese working women. Qualitative Health Research, 20(6), 830-844.

Holroyd-Leduc, J., Resin, J., Ashley, L., Barwich, D., Elliott, J., Huras, P., Légaré, F., Mahoney, M., Maybee, A., McNeil, H., Pullman, D., Sawatzky, R., Stolee, P. \& Muscedere, J. (2016). Giving voice to older adults living with frailty and their family caregivers: engagement of older adults living with frailty in research, health care decision making, and in health policy. Research Involvement and Engagement, 2, 23. 
Research, Society and Development, v. 10, n. 12, e27101220037, 2021 (CC BY 4.0) | ISSN 2525-3409 | DOI: http://dx.doi.org/10.33448/rsd-v10i12.20037

* Horrell, B., Stephens, C., \& Breheny, M. (2015). Capability to care: Supporting the health of informal caregivers for older people. Health Psychology, 34(4), 339-348.

Jacobson, J., Gomersall, J. S., Campbell, J., \& Hughes, M. (2015). Carers' experiences when the person for whom they have been caring enters a residential aged care facility permanently: a systematic review. JBI Database of Systematic Reviews and Implementation Reports, 13(7), 241-317.

* Lane, P., McKenna, H., Ryan, A. \& Fleming, P. (2003). The experience of the family caregivers' role: a qualitative study. Research and theory for nursing practice, $17(2), 137-51$.

* Larrañaga, I., Valderrama, M., Martín, U., Begiristain, J., Bacigalupe, A., \& Arregi, B. (2009). Mujeres y hombres ante el cuidado informal: diferencias en los significados y las estrategias TT [Women and men facing informal caregiving: differences in strategies and meaning.] Rev. Fac. Nac. Salud Pública, 27(1), $50-55$.

Lawrence, V., Murray, J., Samsi, K., \& Banerjee, S. (2008). Attitudes and support needs of black caribbean, south asian and white british carers of people with dementia in the UK. The British Journal of Psychiatry: The Journal of Mental Science, 193(3), 240-246.

Lewin, S., Bohren, M., Rashidian, A., Munthe-Kaas, H., Glenton, C., Colvin, C. J., Garside, R., Noyes, J., Booth, A., Tunçalp, Ö., Wainwright, M., Flottorp, S., Tucker, J. D. \& Carlsen, B. (2018). Applying GRADE-CERQual to qualitative evidence synthesis findings - paper 2: how to make an overall CERQual assessment of confidence and create a Summary of Qualitative Findings table. Implementation Science, 13(S1), 10.

Lewin, S., Booth, A., Glenton, C., Munthe-Kaas, H., Rashidian, A., Wainwright, M., Bohren, M. A., Tunçalp, Ö., Colvin, C. J., Garside, R., Carlsen, B., Langlois, E. V. \& Noyes, J. (2018). Applying GRADE-CERQual to qualitative evidence synthesis findings: introduction to the series. Implementation Science, 13(S1), 2.

Lewis, E. T., Harrison, R., Hanly, L., Psirides, A., Zammit, A., McFarland, K., Dawson, A., Hillman, K., Barr, M., \& Cardona, M. (2019). End-of-life priorities of older adults with terminal illness and caregivers: A qualitative consultation. Health Expectations: An International Journal of Public Participation in Health Care and Health Policy, 22(3), 405-414.

* Lewis, M. B., Curtis, M. P., \& Lundy, K. S. (1995). "He calls me his angel of mercy": the experience of caring for elderly parents in the home. Holistic nursing practice, $9(4), 54-65$.

* Lopez Hartmann, M., Anthierens, S., Van Assche, E., Welvaert, J.,Verhoeven, V., Wens, J. \& Remmen, R. (2016). Understanding the experience of adult daughters caring for an ageing parent, a qualitative study. Journal of Clinical Nursing, 25(11-12), 1693-1702.

Maree, J. E., Moshima, D., Ngubeni, M., \& Zondi, L. (2018). On being a caregiver: The experiences of South African family caregivers caring for cancer patients. European Journal of Cancer Care, 27(2), e12801.

* Mazza, M. M. P. R., \& Lefevre, F. (2005). Caretaking within the family: social representation analysis of the relationship between the caretaker and the elderly. Rev Bras Cresc Desenv Hum, 15(1), 1-10.

Mbanaso, M. U., Shavelson, J., \& Ukawuilulu, J. (2006). Elderly african americans as intragenerational caregivers. Journal of Gerontological Social Work, $47(1-2), 3-15$.

McCabe, M., You, E., \& Tatangelo, G. (2016). Hearing their voice: a systematic review of dementia family caregivers' needs. The Gerontologist, 56(5), e7088.

* McGarry, J., \& Arthur, A. (2001). Informal caring in late life: a qualitative study of the experiences of older carers. Journal of Advanced Nursing, 33(2), 182-189.

Moher, D., Shamseer, L., Clarke, M., Ghersi, D., Liberati, A., Petticrew, M., Shekelle, P., Stewart, L., A \& Group, PRISMA-P. (2015). Preferred reporting items for systematic review and meta-analysis protocols (PRISMA-P) 2015 statement. Systematic Reviews, 4(1), 1.

* Moral-Fernández, L., Frías-Osuna, A., Moreno-Cámara, S., Palomino-Moral, P. A., \& Del-Pino-Casado, R. (2018). Primeros momentos del cuidado: el proceso de convertirse en cuidador de un familiar mayor dependiente. [The first moments of the carer: The process of becoming a caregiver of a dependent elderly relative] Atención Primaria, 50(5), 282-290.

Munthe-Kaas, H., Bohren, M. A., Glenton, C., Lewin, S., Noyes, J., Tunçalp, Ö., Booth, A., Garside, R., Colvin, C. J., Wainwright, M., Rashidian, A., Flottorp, S., \& Carlsen, B. (2018). Applying GRADE-CERQual to qualitative evidence synthesis findings - paper 3: how to assess methodological limitations. Implementation Science, 13(S1), 9.

Noyes, J., Booth, A., Lewin, S., Carlsen, B., Glenton, C., Colvin, C. J., Garside, R., Bohren, M. A., Rashidian, A., Wainwright, M., Tunçalp, Ö., Chandler, J., Flottorp, S., Pantoja, T., Tucker, J. D., \& Munthe-Kaas, H. (2018). Applying GRADE-CERQual to qualitative evidence synthesis findings-paper 6: how to assess relevance of the data. Implementation Science, 13(S1), 4.

Ouzzani, M., Hammady, H., Fedorowicz, Z., \& Elmagarmid, A. (2016). Rayyan - a web and mobile app for systematic reviews. Systematic Reviews, 5(1), 210.

* Paillard-Borg, S., \& Strömberg, L. (2014). The importance of reciprocity for female caregivers in a super-aged society: a qualitative journalistic approach. Health Care for Women International, 35(11-12), 1365-1377.

Parker, K., Hickman, L. D., Phillips, J. L., \& Ferguson, C. (2020). Interventions to optimise transitional care coordination for older people living with dementia and concomitant multimorbidity and their caregivers: a systematic review. Contemporary Nurse, 1-45.

* Peacock, S., Sethi, B., Williams, A., Duggleby, W., Bayly, M., Swindle, J., Ploeg, J., \& Markle-Reid, M. (2017). Older adult spouses with multiple chronic conditions: challenges, rewards, and coping strategies. Canadian Journal on Aging, 36(2), 209-222. 
Research, Society and Development, v. 10, n. 12, e27101220037, 2021

(CC BY 4.0) | ISSN 2525-3409 | DOI: http://dx.doi.org/10.33448/rsd-v10i12.20037

* Pedreira, L. C., Ferreira, A. M. C., Silva, G. T. R., Silva, R. M. O., \& Freitas, C. M. (2018). Older Brazilian caregivers and their lived experiences of caring -

A hermeneutic phenomenological study. Journal of Clinical Nursing, 27(17-18), 3314-3323.

* Piercy, K. W. (2007). Characteristics of strong commitments to intergenerational family care of older adults. The Journals of Gerontology Series B: Psychological Sciences and Social Sciences, 62(6), S381-S387.

Ringer, T., Hazzan, A. A., Agarwal, A., Mutsaers, A., \& Papaioannou, A. (2017). Relationship between family caregiver burden and physical frailty in older adults without dementia: a systematic review. Systematic Reviews, 6(1), 55.

* Rodger, D., Neill, M. O., \& Nugent, L. (2015). Informal carers' experiences of caring for older adults at home: a phenomenological study. British Journal of Community Nursing, 20(6), 280-285.

Saletti-Cuesta, L., Tutton, E.; Langstaff, D., \& Willett, K. (2018). Understanding informal carers' experiences of caring for older people with a hip fracture: a systematic review of qualitative studies. Disability and Rehabilitation, 40(7), 740-750.

Sandelowski, M., \& Barroso, J. (2007). Handbook for Synthesizing Qualitative Research. (Springer Publishing Company, Hrsg.).

Scazufca, M. (2002). Brazilian version of the Burden Interview scale for the assessment of burden of care in carers of people with mental illnesses. Revista Brasileira de Psiquiatria, 24(1), 12-17.

* Six, S., Musomi, S., \& Deschepper, R. (2019). Are the elderly perceived as a burden to society? The perspective of family caregivers in belgium and kenya: a comparative study. Journal of Transcultural Nursing, 30(2), 124-131.

Stern, C., Jordan, Z., \& McArthur, A. (2014). Developing the review question and inclusion criteria. AJN, American Journal of Nursing, 114(4), 53-56.

Thomas, J., \& Harden, A. (2008). Methods for the thematic synthesis of qualitative research in systematic reviews. BMC Medical Research Methodology, 8(1), 45 .

Thorne, S., Jensen, L., Kearney, M. H., Noblit, G. \& Sandelowski, M. (2004). Qualitative metasynthesis: reflections on methodological orientation and ideological agenda. Qualitative Health Research, 14(10), 1342-1365.

Tong, A., Flemming, K., McInnes, E., Oliver, S., \& Craig, J. (2012). Enhancing transparency in reporting the synthesis of qualitative research: ENTREQ. BMC Medical Research Methodology, 12(1), 181.

Turato, E. R. (2005). Qualitative and quantitative methods in health: definitions, differences and research subjects. Revista de Saúde Pública, 39(3), 507-514.

Vallée, A., \& Vallée, J. (2017). Experience for caregivers of dependent elderly persons with dementia. Gériatrie et Psychologie Neuropsychiatrie du Viellissement, 15(2), 138-144.

Watson, B., Tatangelo, G., \& McCabe, M. (2019). Depression and anxiety among partner and offspring carers of people with dementia: a systematic review. The Gerontologist, 59(5), e597-e610.

WHO. World Health Organization (2015). The growing need for home health care for the elderly: home health care for the elderly as an integral part of primary health care services. World Health Organization.

WHO. World Health Organization. (2017). Integrated care for older people: guidelines on community-level interventions to manage declines in intrinsic capacity. Geneva: World Health Organization.

* Williams, A., Sethi, B., Duggleby, W., Ploeg, J., Markle-Reid, M., Peacock, S., \& Ghosh, S. (2016). A Canadian qualitative study exploring the diversity of the experience of family caregivers of older adults with multiple chronic conditions using a social location perspective. International Journal for Equity in Health, 15(1), 40 .

Woodford, J., Farrand, P., Watkins, E. R., \& LLewellyn, D. J. (2018). “I don't believe in leading a life of my own, I lead his life": a qualitative investigation of difficulties experienced by informal caregivers of stroke survivors experiencing depressive and anxious symptoms. Clinical Gerontologist, 41(4), 293-307.

Zimmer, L. (2006). Qualitative meta-synthesis: a question of dialoguing with texts. Journal of Advanced Nursing, 53(3), 311-318. 